\title{
TANULÁS A FÖLD KÖRÜL
}

\author{
DARU ANDREA
}

ELTE PPK Neveléstudományi Doktori Iskola

Elizabeth Hultquist, Sverker Lindblad \& Thomas S. Popkewitz: Critical Analyses of Educational Reforms in an Era of Transnational Governance. Cham, 2018. Springer. $\mathrm{xi}+280$ p. ISBN 978-3-319-61971-2 (eBook)

A századfordulón induló, azóta is tartó reformok, köztük legfőképp az oktatási reformok sarkalatos és állandó kérdéseket vetnek fel társadalmunkban. A fejlődés üteme napjainkra mit sem vesztett energiájából, és ez alól a világ egyik országa sem kivétel. Elizabeth Hultquist, Sverker Lindblad és Thomas S. Popkewitz, a tanulmánykötet szerkesztői, a világban zajló oktatási folyamatokat, törekvéseket és azok hatásait vizsgálták gazdaságilag, politikailag, társadalmilag, és nem utolsó sorban a gyerekek, tanulók szempontjából. Munkájukat segítette tizenöt kutató a világ legkülönbözőbb országaiból, akik saját nemzetük oktatási rendszerének vizsgálatai révén elismert szakembereknek számítanak. A tanulmánykötetben Portugália, Dánia, Anglia, Mexikó, Spanyolország, Svédország, Ausztrália, Amerika, Belgium és Kína is képviselteti magát. A szerkesztők célja a kritikai elemzéssel párhuzamosan egy színes, részletes és átfogó kép alkotása volt, amely segítséget nyújt nemcsak a világ, hanem a különböző nemzetek oktatási rendszereinek, szervezeteinek és azok egymás közti kapcsolatainak feltérképezéséhez és megértéséhez.

Robert Cowen a pedagógiai reformok két jelentős periódusát különbözteti meg. 1945 körül kezdődően egyfajta ke- resztes hadjáratként vonul végig számos országban az a törekvés a politikában, hogy az egyenlő tanulási esélyek kívánalma kerüljön a napirendi pontok középpontjába. $\mathrm{Az}$ összehasonlító pedagógia ebben az időszakban a politikareform egyik alappillére lesz. 1990-től szintén a keresztes hadjáratokat idézi a gazdasági globalizáció folyamata és az igény az oktatási rendszerek újragondolására. Mindkét periódusban megfigyelhető, hogy az összehasonlító pedagógia folyamatos átformálódása szorosan összefügg a nemzetközi, politikai és gazdasági változásokkal. Megjelennek a módszerre jellemző mérések és az erre a szisztémára alapuló új iskolák (OECD és PISA, „world-class university”). Ha ezeknek a szervezeteknek a munkáját kritikus szemmel, mélyebben is megvizsgáljuk, részletes és mélyreható képet kapunk a világban végbemenő oktatási folyamatokról. Cowen szerint azonban még így is maradnak megválaszolatlan kérdések, melyek teret nyithatnak a jövő új kutatói számára: „Mennyit szabad megismernünk a gyakorlati értékekből a különböző nemzetek oktatási rendszereinek tanulmányozása során?” „Vajon az összehasonlító pedagógia a vezetés egy módszere, vagy inkább egy történelmi utazás?” 
Hogyan változnak a politikai termelés és rendelkezés terei? Erre a kérdésre ad választ Lingard oktatáspolitikai analízise. Napjaink globális oktatási rendszerének két meghatározó nem állami szereplőjét említi: az OECD-t és szellemi termékét, a PISA-t, valamint az oktatási piac (edubusiness) idehaza is jól ismert képviselőjét, a Pearsont. Tevékenységük révén jól kirajzolódnak oktatási rendszereink problémái. Jól tudott, hogy a PISA-mérések révén számtalan adat gyủlik össze a tanulók képességeiről, ám úgy tűnik, ezek hasznosítása alig jelenik meg a nemzeti oktatáspolitikákban, ez a fajta tanulás (policy learning) egyelőre várat magára. Persze minden nemzet kultúrája és szokásrendszere más, következésképp az egyes országok eltérő oktatási rendszerrel rendelkeznek, az életkoruk alapján kiválasztott gyerekek eredményei nehezen összehasonlíthatók. Lingard tanulmánya részletesen vázolja Amerika, Anglia és Ausztrália nézőpontját a PISA-teszttel kapcsolatban.

Az oktatási reformokat érdemes transznacionalizációs szempontból is elemezni. A következőkben a különböző nemzetközi reformok folyamatainak egy-egy országra gyakorolt hatásaival foglalkozunk.

Svédország oktatási rendszere radikálisan megváltozott a II. világháború után, írja Lindblad. A változás kisebb egységekben, szakaszosan következett be. A háborút követő első harmincéves periódusban a skandináv jóléti országban aranykor köszöntött be a társadalmi folyamatok irányításában. Különleges figyelmet szenteltek az oktatásnak. A svéd modell alapjául a társadalmi problémák megoldása szolgált egy központosított döntéshozatal megteremtésével együtt. A következő tíz esztendőben már megmutatkoztak a központosítás negatív eredményei. 1990-től egy új, angol modell alakította át a rendszert. Ennek alapja a szabályok alóli felmentés, a privatizáció és a piacosodás folyamat volt. Ez a hármas egység egy kreatív, felszabadult és fejlődőképes oktatáspolitikát eredményezett, mely kisebb-nagyobb nehézségekkel, de mind a mai napig eredményesen müködik.

$\mathrm{A} z$ iskolaválasztás problematikáját és folyamatait, szintén Svédországban, Hultqvist jegyzi. Az oktatás helyzete, mint a világ számos országában, itt is kulcsfontosságú szerepet tölt be a politikában. 1992-re datálható az ún. iskolaválasztási reform, mely Svédország oktatásában napjainkban is meghatározó erővel bír. Célja az volt, hogy eltörlődjenek az iskolaválasztási kötöttségek: ne az önkormányzatok jelöljék ki az iskolákat a gyerekek számára. Ezzel az újítással a gyerekek és szülők önálló döntésre kaptak lehetőséget. A reform az oktatás finanszírozási formáját is átalakította: az önkormányzatok anyagi támogatása helyett minden gyerek iskolai utalványt (school voucher) kapott. Ez a finanszírozási forma új iskolák (charter school) megjelenéséhez vezetett, és egyúttal versenyszerű, szegregált iskolarendszert alakított ki. Hulqvist tanulmányából láthatjuk, hogyan kapcsolódnak az iskolaválasztási lehetőségek a különböző társadalmi csoportok igényeihez és elvárásaihoz. Az oktatási rendszer ilyenfajta átalakítása a svéd iskolarendszer szegregáltságának erősödéséhez vezetett, különösen a nagyvárosokban.

Dánia tanárképzési programja jellegzetesen nemzeti szakmai alapokra épül, mely korunkban a modern egyetem formájában megtestesülve egyre jobban alkalmazkodik a transznacionális mintákhoz, bár svéd szomszédjához képest a folyamat lassabb ütemben zajlik. A különböző oktatási szervezetek, az EU és az OECD tevékenységei gyakran heves vitát váltanak ki a politikában, Svédországban és Dániában egyaránt, a bolognai rendszer pedig még mindig ismeretlen a szélesebb 
közönség számára. Mindemellett azonban általánosan elterjedt az élethosszig tartó tanulás, a fiatalok könnyedén helytállnak a versenyorientált, tudásalapú gazdaságban. Az azonban itt is világossá válik, hogy a tanulók megfelelő ütemű és minőségü fejlődésének legfontosabb kulcsa a pedagógus személye, képessége, munkájának minősége.

Svájc oktatási rendszerének sikeressége a kantonok önállóságában rejlik. Minden kanton saját szabályrendszerrel múködik, melyben a kulturális célok mellett mindenekelött a társadalmi rend értékeit fektették le. Az elmúlt években megkísérelték összevonni a kantonok oktatási rendszereit, hogy egységes, erős iskolamodellt hozzanak létre. Ezzel a céllal jött létre az ún. HarmoS (Harmonizing Switzerland) és a (német nyelvü kantonokat érintő) Curriculum 21. Sokan vélik úgy azonban, hogy az egységes svájci iskolarendszer kialakítása helyett sokkal fontosabb, és így nagyobb figyelmet kellene fordítani arra, hogy hogyan múködik az oktatás az osztálytermeken belül.

Vessünk most néhány pillantást az iskolarendszerekre a gyerekek, tanulók szemszögéből. Milyen igényeik vannak? Hogyan küzdenek a tanulási lehetőségekért a szegényebb, elmaradottabb régiókban? Hogyan épül fel az SNI-s gyermekek képzése különböző országokban, és ezek a formák hogyan kapcsolódnak nemzetközileg egymáshoz? Ezekre a kérdésekre ad választ a tanulmánykötet a harmadik fejezetben.

$\mathrm{Az}$ olyan transznacionális irányelvek, mint a Salamancai Nyilatkozat vagy az ENSZ Fogyatékkal Élők Jogainak Egyezménye (UN Convention on Rights of Person with Disabilities) mind a mainál inkluzívabb, a tanulói sokszínűségre könnyebben reagáló oktatási rendszerekért harcolnak. Európában azonban egyre inkább terjed a differenciált oktatás és az egyénre szabott képzések gyakorlata. $\mathrm{Az}$ egyéni nevelési igényekkel rendelkező gyerekek oktatása mellett fontos itt megemlíteni az egyre népszerübb, ún. független oktatást (Independent Learning) vagy az otthon tanulást.

Napjainkban megkerülhetetlenné váltak az elektronikai eszközök az oktatásban, számos reform is rájuk épül. Korunk talán egyik legnagyobb problémaforrása a digitális média használata az osztályteremben. Számos kérdést vet fel szükségességük, hasznuk, eredményességük ezeknek az eszközöknek. A pozitív eredményeket az Argentínában bevezetett, Minden tanulónak egy notebookot program igazolja, amelyben megpróbálták áthidalni az ürt a digitális média és a különösen elmaradott vagy szegény környezetben élő gyermekek között.

Végül, de nem utolsósorban, ha nemzetek közötti kapcsolódásról, irányításról, transznacionalizációról beszélünk, akkor elkerülhetetlenül felbukkan a migráció kérdése. E globális probléma két, egymástól nagyon különböző és távol eső ország, Spanyolország és Kína példáján keresztül jelenik meg a könyvben. Spanyolországban két periódusát lehet említeni a migrációs folyamatoknak, a társadalmi és gazdasági krízis előttit és utánit. A Katalóniából való emigrálást problémaként értelmezték mindkét szakaszban, ám napjainkra már olyan eseményként is tekintenek rá, ami elősegítheti az oktatás újragondolását, egy új rendszer kialakítását, melyben mindenki megtalálhatja a számára megfelelő tanulási formát és teret.

Kínában a migráció folyamata az ország határain belül történik. „Sodródó gyermekeknek" (floating children) nevezik azokat a fiatalokat, akik a vidéki elmaradott környezetből a nagyvárosokba települnek. Fokozódó érdeklődéssel fordulnak a probléma felé a kutatók és a politikai törvényhozók egyaránt. Ezek a 
fiatalok a városiasodás és modernizálódás termékének tekinthetők, akiknek komoly küzdelmet jelent elszakadni gyökereiktől és adaptálódni egy teljesen új, ismeretlen környezethez. Az új környezet és új képzési lehetőségek azonban nem garantálják a fiataloknak a kiemelkedést korábbi életszínvonalukból, gyakran előfordul, hogy szüleik társadalmi szintjén folytatják felnőtt életüket. A kutatók elképzelése szerint a kormánynak fel kellene gyorsítania a városiasodás folyamatát, hogy megfelelő mennyiségü és színvonalú tanulási lehetőséget teremtsenek a városokba áramló népességnek. Továbbra is megoldandó problémának tekintik a vidékről érkezett emberek megbélyegzését, sztereotípiákba zárását.

Befejezésképp álljon itt a szerzők néhány gondolata a tanulmánykötet jelen- tőségét illetően: „A kötetben található tudományos közlemények kritikus értelmezéseket és magyarázatokat adnak arra a kérdésre, hogy az oktatás reformjai mit takarnak társadalmilag, történelmileg és kulturális szemszögből egy adott időben. A könyv az oktatás és az oktatási rendszerek szemléletmódjainak változásaira fókuszál: hogyan válaszol az iskolai és a felnőttoktatás a hatékonyság és eredményesség értekezéseire, valamint a saját, sémák szerinti átformálódására. Az ilyen változó szemléletek magyarázzák, mit jelent az oktatás és a hozzá kapcsolódó folyamatok, valamint fontos szerepet töltenek be az oktatási ismeretek és az oktatás kritikai diskurzusainak azonosításában és elemzésében." (1. o.)

A cikk a Creative Commons Attribution 4.0 International License (https://creativecommons.org/licenses/ by/4.0/) feltételei szerint publikált Open Access közlemény, melynek szellemében a cikk bármilyen médiumban szabadon felhasználható, megosztható és újraközölhető, feltéve, hogy az eredeti szerző és a közlés helye, illetve a CC License linkje és az esetlegesen végrehajtott módosítások feltüntetésre kerülnek. (SID_1) 